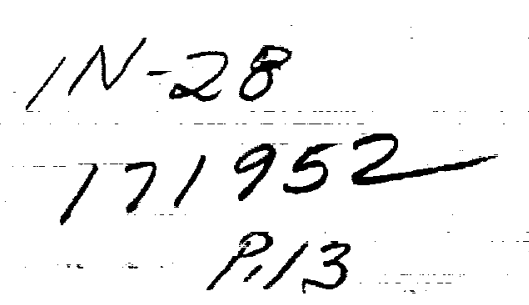

AIAA-93-2244

\title{
Benefits of In Situ Propellant Utilization for a Mars Sample Return Mission
}

Mary F. Wadel

Lewis Research Center

Cleveland, Ohio

Prepared for the

29th Joint Propulsion Conference and Exhibit

cosponsored by the AIAA, SAE, ASME, and ASEE

Monterey, California, June 28-30, 1993

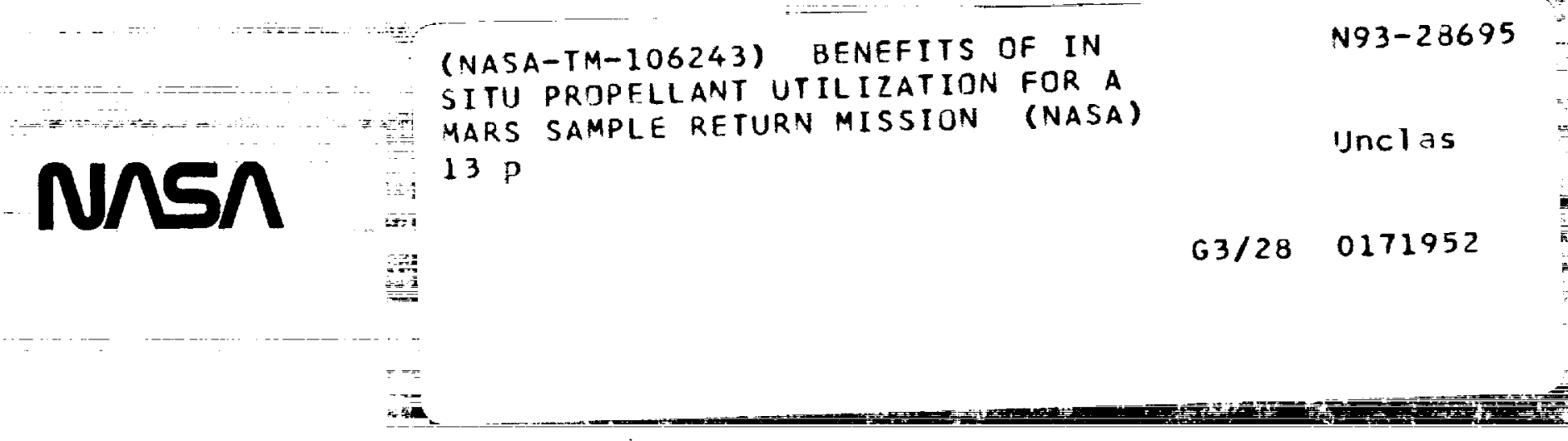




\title{
Benefits of In Situ Propellant Utilization for a Mars Sample Return Mission
}

\author{
Mary F. Wadel ${ }^{\dagger}$ \\ National Aeronautics and Space Administration \\ Lewis Research Center \\ Cleveland, Ohio 44135
}

\begin{abstract}
Previous Mars rover sample return mission studies have shown a requirement for Titan IV or STS Space Shuttle launch vehicles to complete a sample return from a single Mars site. These studies have either used terrestrial propellants or considered in situ production of methane and oxygen for the return portion of the mission. 'Using in situ propellants for the return vehicle reduces the Earth launch mass and allows for a smaller Earth launch vehicle, since the return propellant is not carried from Earth. Carbon monoxide and oxygen $\left(\mathrm{CO} / \mathrm{O}_{2}\right)$ and methane and oxygen $\left(\mathrm{CH}_{4} / \mathrm{O}_{2}\right)$ were investigated as in situ propellants for a Mars sample return mission and the results were compared to a baseline study performed by the Jet Propulsion Laboratory using terrestrial propellants. Capability for increased sample return mass, use of an alternate launch vehicle, and an additional mini-rover as payload were included in the present study. $\mathrm{CO} / \mathrm{O}_{2}$ and $\mathrm{CH} / / \mathrm{O}_{2}$ were found to decrease the baseline Earth launch mass by 13.6 and 9.2 percent respectively. This resulted in higher payload mass margins for the baseline Atlas IIAS launch vehicle. $\mathrm{CO} / \mathrm{O}_{2}$ had the highest mass margin. And because of this, it was not only possible to increase the sample return mass and carry an additional minirover, but was also possible to use the smaller Atlas IIA launch vehicle.
\end{abstract}

\section{Introduction}

Mars rover sample return missions have been proposed for over a decade. 1- $^{-6}$ These proposals require Titan IV or STS Space Shuttle launch vehicles and collect a sample from a single Mars site. For the return leg from Mars, these studies have considered the use of terrestrial propellants or some form of in situ propellant production - only oxygen or methane and oxygen. Using terrestrial propellants requires all of the retum leg propellants to be launched from the Earth surface. $t$ - Member, ALAA.

Copyright 1993 by the American Institute of Aeronautics and Astronautics, Ioc. No copyright is asserted in the United States under Title 17, U.S. Code. The U.S. Government has a royalty-free license to exercise all rights under the copyright elaimed hereio for governmenul purposes. All other rights are reserved by the copyright owder.
Using in situ propellants eliminates some or all of the return propellants from the Earth launch mass; thereby decreasing the launch mass, even with the inclusion of an in situ propellant production plant mass.

Since the Mars atmosphere is composed of approximately 95 percent carbon dioxide, ${ }^{7}$ both carbon monoxide and oxygen $\left(\mathrm{CO} / \mathrm{O}_{2}\right)$ and methane and oxygen $\left(\mathrm{CH}_{4} / \mathrm{O}_{2}\right)$ are attractive candidates for in situ propellants. Both of the fuels and the oxygen could be obtained with the use of a production plant at the landing site. $\mathrm{CO} / \mathrm{O}_{2}$ is the most advantageous candidate, since it requires no consumables to be brought from Earth. However, it gives a relatively low specific impulse (292 sec, at a 0.55 mixture ratio) in comparison to a hydrogen and oxygen system $(470 \mathrm{sec}$, at a 6.0 mixture ratio). Methane is an alternative since it requires only the hydrogen to be brought from Earth and delivers a specific impulse much higher $(379 \mathrm{sec}$, at a 3.5 mixture ratio) than $\mathrm{CO} / \mathrm{O}_{2}{ }^{8}$

A Mars sample return mission study performed by the Jet Propulsion Laboratory(JPL) using terrestrial propellants was used as a baseline mission. ${ }^{1}$ It was chosen as a baseline mission because it not only is able to use a smaller launch vehicle than past studies, but is also able to visit two different Mars sites per Earth launch. The mission employs heavy use of microtechnology for the mini-rover and lightweight miniaturized technology for the propulsion system to return a $1.0 \mathrm{~kg}$ sample per Earth launch. Two sample return vehicles are in each payload and return $0.5 \mathrm{~kg}$ each. It takes a spartan approach with minimal redundancy; therefore, making the payload light compared to previous studies. Because of the microtechnology, miniaturized technology, and minimal redundancy, an intermediate launch vehicle can be used, specifically an Atlas IIAS. The mission is proposed for a flight between the years 2001 and 2009 . For the launch opportunities between 2001 and 2009, the smallest Earth launch mass margin is 2.7 percent using an Atlas IIAS as the launch vehicle. Mass margin indicates the amount of remaining available payload mass for the specific launch vehicle. Ideally, the baseline mission could be flown, since there is 2.7 percent of payload still available. But, at early stages of 
design a limited mass margin is undesirable, since significant unplanned changes could occur during the development stage. However, using in situ propellants in place of the baseline terrestrial propellants could greatly increase the mass margin. This increase in Earth launch mass margin would allow for a larger sample to be returned, a smaller launch vehicle to be employed, or increased redundancy in the system - such as an additional mini-rover - to insure mission success.

This paper investigates the use of the in situ propellants $\mathrm{CO} / \mathrm{O}_{2}$ and $\mathrm{CH}_{4} / \mathrm{O}_{2}$ for the baseline mission defined in Ref. 1 in place of terrestrial propellants for Mars ascent and Earth return. Increasing sample return mass, using an alternate launch vehicle, or including an additional mini-rover as payload were the objectives.

\section{Baseline Mission Model}

The mission scenario, as defined by JPL in Ref. 1 , is described below. The mission model proposes four launches each carrying two separate sample return vehicles. This results in eight vehicles reaching the surface of Mars to each return a $0.5 \mathrm{~kg}$ sample. Two launches would be conducted within the same launch window opportunity. The mission model begins with the first two launches in 2006 . However, the mission could be operated at opportunities from 2001 to 2009. Table 1 presents the launch opportunities between 2001 and 2009.

Launch of the first two sample return vehicles is on November 21, 2006 using an Atlas IIAS. After trans-Mars injection the two vehicles separate and travel to Mars independently. Approximately ten days later. the second launch of two more sample return vehicles is conducted. Again the vehicles separate to travel to Mars. The launch window for both launches is $\mathbf{3 0}$ days, which ends on December 20, 2006.

The four sample return vehicles arrive at Mars from January 18 to March 1, 2009. Trajectory correction maneuvers (TCM) are used to place only one vehicle at Mars within a single 24-hour period and to place it in the correct landing area.

The sample return vehicles employ the use of a blunt cone aeroshell (BCA) for atmospheric entry and a parachute and propulsive terminal descent for a soft landing. For a period from 128 to 170 days, each sample return vehicle's mini-rover makes at least 10 traverses and retains at least 5 samples in its area for its $0.5 \mathrm{~kg}$ return sample.

Each sample return vehicle's Mars ascent return vehicle (MARV) is launched to orbit when $0.5 \mathrm{~kg}$ of acceptable samples has been collected and transferred to its sample return canister (SRC). The latest launch to orbit would occur in a 16-day period from July 7 to July 23. 2009. Mars-Earth transfer is performed on all four vehicles between July 25 and August 3, 2009. Table 2 gives the Mars launch opportunities between 2003 and 2011 corresponding to the original Earth launches.

In May 2010, the MARV returns to Earth. The SRC is separated from the MARV two days before Earth arrival. The MARV is then deflected to miss Earth, while the SRC continues toward Earth for atmospheric entry. The return sample is recovered by air snatch.

The entire mission sequence is repeated in October 2009 to return four more samples from four more sites. This mission arrives at Mars in September 2010, stays 11 months and returns to Earth in July 2012. After both missions, a total of $4 \mathrm{~kg}$ of sample from 8 sites would be achieved.

\section{Sample Return Vehicle Description}

Each Earth launch carries two sample return vehicles. These vehicles each carry a BCA, a landing system, a mini-rover, a MARV, and a SRC. Figure 1 shows the complete baseline sample return vehicle, which would be launched from Earth.

The baseline propulsion systems use nitrogen tetroxide (NTO) and monomethylhydrazine (MMH) for the trajectory correction and terminal descent maneuvers upon arrival at Mars. This is to minimize contamination of the landing site upon arrival. Chloropentafluoride $\left(\mathrm{CIF}_{5}\right)$ and hydrazine $\left(\mathrm{N}_{2} \mathrm{H}_{4}\right)$ are used for both the main engines and the reaction control systems (RCS) for the MARV's first and second stages. $\mathrm{ClF}_{5}$ and $\mathrm{N}_{2} \mathrm{H}_{4}$ provide a higher specific impulse (360 $\mathrm{sec}$ ) and lower propulsion system mass than NTO and MMH (specific impulse of $350 \mathrm{sec}$ ). The propellant tanks are made from an aluminum-lined, carbon-wound material, which keeps the tank mass to a maximum of $1.76 \mathrm{~kg}$ each for the baseline mission.

The engines used in the baseline mission take advantage of lightweight miniaturized technology currently being developed. This allows for a high performance pressure-fed system with a chamber pressure of $6.89 \mathrm{MPa}$, an area ratio of 300 for the $\mathrm{CIF}_{4}$ $\mathrm{N}_{2} \mathrm{H}_{4}$ engines or 400 for the NTO/MMH engines, and engine masses of 0.02 to $1.45 \mathrm{~kg}$ for thrusts of $0.02 \mathrm{kN}$ to $2.22 \mathrm{kN}$.

When using the in situ propellants, many of the engine and tank parameters were kept the same as the baseline. This was to keep the in situ MARV's as close 
as possible to the baseline mission with only a propellant change. $\mathrm{CO} / \mathrm{O}_{2}$ and $\mathrm{CH}_{4} / \mathrm{O}_{2}$ are cryogenic propellants and have different specific impulses from the storable $\mathrm{ClF} \mathrm{F}_{2} \mathrm{~N}_{2} \mathrm{H}_{4}$. Therefore, the baseline engine and propellant tank sizes would not be correct for either in situ case. Figure 2 shows how the MARV tanks are arranged in both the first and second stage. The MARV has room to increase in diameter without complete reconfiguration of the vehicle (see Figure 1). Therefore, the engine size (scaled with thrust) and the propellant tank radius was allowed to change to accommodate the in situ propellants.

For the in situ propellants, the only addition to the sample return vehicle at Earth Jaunch was to include a production plant for the propellants. Adding the production plant would cause some change to the sample return vehicle. One possible placement of the production plant is near the landing system and MARV interface. As seen in Figure 1, sufficient volume exists in the sample return vehicle to accommodate the production plant.

\section{Bropellant Production}

Propellant production on the surface of Mars for $\mathrm{CO} / \mathrm{O}_{2}$ and $\mathrm{CH}_{4} / \mathrm{O}_{2}$ is described below. Both processes begin with taking carbon dioxide $\left(\mathrm{CO}_{2}\right)$ from the Mars atmosphere and using it to make the fuel and oxygen. They also have a filtering device to remove the martian dust from the $\mathrm{CO}_{2}$ to prevent contamination of the processes.

\section{Carbon Monoxide and Oxygen Production}

Carbon monoxide and oxygen production from the Mars atmosphere occurs through two mechanisms. The first is an oxygen separator that relies on an array of yttria stabilized zirconia electrolyte cells. The second is a carbon monoxide separator which relies on a $\mathrm{CO}$ adsorbent material containing copper (I) $\left(\mathrm{Cu}^{+}\right)$.

The system begins with the carbon dioxide from the Mars atmosphere being brought in through a $\mathrm{CO}_{2}$ adsorption compressor. From the compressor, the $\mathrm{CO}_{2}$ is sent through a heat exchanger. The $\mathrm{CO}_{2}$ is then passed into a zirconia cell array where the $\mathrm{CO}_{2}$ is heated and partially dissociated into $\mathrm{CO}$ and $\mathrm{O}_{2}$. The zirconia cells pass the oxygen to storage tanks and exhaust $\mathrm{CO}_{2}$ and $\mathrm{CO}$. This exhaust is directed into the carbon monoxide separator. A more detailed discussion of the oxygen production process can be found in Ref.9.

In the carbon monoxide separator there is an adsorbent material of activated $\mathrm{Al}_{2} \mathrm{O}_{3}$ spheres. An inner layer of carbon and outer layer of cuprous chloride $(\mathrm{Cu}+\mathrm{Cl})$ is on the $\mathrm{Al}_{2} \mathrm{O}_{3}$ spheres. The $\mathrm{Cu}^{+}$preferentially adsorbs the $\mathrm{CO}$ over the $\mathrm{CO}_{2}$. The $\mathrm{CO}$ in the $\mathrm{CO}_{2}$ and $\mathrm{CO}$ exhaust from the zirconia cells is then adsorbed onto the spheres and the remaining $\mathrm{CO}_{2}$ is vented. Heating the adsorbent spheres allows the collected $\mathrm{CO}$ to desorb and be collected into storage tanks.

\section{Methane and Oxygen Production}

Using the Sabatier reaction the methane and oxygen is produced on the Mars surface with the available $\mathrm{CO}_{2}$ in the Mars atmosphere and hydrogen brought from Earth. The Sabatier reaction is given below:

$$
\mathrm{CO}_{2}+4 \mathrm{H}_{2}=\mathrm{CH}_{4}+2 \mathrm{H}_{2} \mathrm{O}
$$

The water created from the Sabatier reaction is then sent through an electrolysis cell to separate the hydrogen and oxygen with the reaction:

$$
2 \mathrm{H}_{2} \mathrm{O}=2 \mathrm{H}_{2}+\mathrm{O}_{2}
$$

The hydrogen is then recycled back through the Sabatier reaction to produce more methane.

This process produces a mixture ratio of 2 for the methane and oxygen. The desired mixture ratio for optimum performance from the propellant is 3.5 . To obtain more oxygen, some of the methane produced is pyrolyzed into carbon and hydrogen with the reaction:

$$
\mathrm{CH}_{4}=\mathrm{C}+2 \mathrm{H}_{2}
$$

The hydrogen gained by this is sent back through the Sabatier reaction and electrolysis processes to produce the oxygen.

One final process is required to complete the production plant. The pyrolyzing process of the methane causes a carbon deposit within the reaction chamber. The build up could be cleaned out by venting hot $\mathrm{CO}_{2}$ gas into the chamber to form $\mathrm{CO}$ which could be exhausted into the atmosphere. The reaction for this is:

$$
\mathrm{CO}_{2}+\mathrm{C}=2 \mathrm{CO}
$$

A more detailed discussion of the production of methane and oxygen on the Mars surface is given in Ref.2. 


\section{In Situ Mass Estimations}

Launch masses for each mission were determined using an iterative process for each stage of the mission. To keep the in situ missions as close as possible to the baseline mission, many of the baseline elements were held constant. Table 3 lists these elements and their values. Propellant, tank, and engine masses were varied based on the propellant used for the MARV.

To determine the propellant mass for each stage of the mission the rocket equation was used. This equation is:

$$
\Delta V=g_{e} \cdot I_{s p} \cdot \ln \left(m_{i} / m_{b o}\right)
$$

The specific impulse $\left(I_{\text {sp }}\right)$ was found using the Complex Chemical Equilibrium Composition (CEC) computer program. ${ }^{10}$ The delta-V's $(\Delta V)$ were from the baseline mission (see Table 3 ). Since the same baseline $C_{3}$ 's (the square of the excess transfer velocity) were used, the same baseline $\Delta V$ 's were used for each mission stage. The initial and burnout masses $\left(m_{i}\right.$ and $\left.m_{60}\right)$ were iterated upon with tank and engine masses until the change was within one percent.

Propellant tank masses for all stages of the mission were determined using thin walled pressure vessel theory. From the baseline mission, an operating pressure of $10.0 \mathrm{MPa}$ was used for the propellant tanks. The pressurant operating pressure was $68.9 \mathrm{MPa}$. The safety and flange factors assumed were 2.0 and 1.4 respectively. The tanks used the baseline aluminumlined and carbon-wound material, which has a density of $1746 \mathrm{~kg} / \mathrm{m}^{3}$. The number and length of the tanks were kept the same as the baseline and tank radius was varied. For the $\mathrm{CH}_{4} / \mathrm{O}_{2}$ case an extra tank was added to bring the hydrogen needed for production.

Engine masses were determined from empirical data from lightweight miniaturized engine studies.' With these studies, the engine mass was related, for the same chamber pressure and area ratio, to engine thrust. Engine thrust was determined from the total thrust for each MARV stage using the $2.3 \mathrm{~g}_{\text {Mars }}$ initial acceleration calculated from the baseline mission and assuming the same number of engines as the baseline.

Production plants for the in situ missions were estimated with redundancy in the production plant's components and valves. The daily propellant production was calculated from the amount of return propellant needed divided by twice the shortest mission stay of 128 days. Twice the shortest mission stay was used for the propellant production rate to keep power and mass as low as possible (RTG's were used as the power source). Table 2 shows that only one mission is shorter than 256 days. For this single mission, the redundant systems could be used together to produce the required propellant. For the $\mathrm{CO} / \mathrm{O}_{2}$ mission the production plant mass was determined using methods described in Ref. 11. For the $\mathrm{CH}_{4} / \mathrm{O}_{2}$ mission the production plant mass was determined from Ref. 2.

Total Earth launch mass was defined as twice the mass of a single sample return vehicle, since each launch carries two vehicles, with an additional three percent launch vehicle adaptor mass. The launch vehicle adaptors are used to hold the two sample return vehicles in the payload fairings.

To determine the Earth launch mass margins, the Atlas IAS and Atlas $\Pi$ A were used as potential Earth launch vehicles. Mass margin was determined by:

MassMargin $=\frac{\text { Atlas PayloadMass }- \text { TotalEarthLaunchMass }}{\text { TotalEarthLaunchMass }}$

The current launch vehicle payload mass capabilities were obtained from Ref. 12. The baseline mission used this reference to determine the Earth launch payload masses; however, at that time the reference had only reached revision $\mathbf{A}$. For this study, the current revision $B$ numbers were used.

\section{Results and Discussion}

The baseline MARV propulsion systems were replaced with $\mathrm{CO} / \mathrm{O}_{2}$ and $\mathrm{CH}_{4} / \mathrm{O}_{2}$ systems to determine the advantages of in situ propellant use. Sample return mass, launch vehicle type, and additional mini-rovers were then considered. From this the sample return vehicle masses, Earth launch masses, and launch mass margins were determined. These results are presented here.

The first investigation followed the original baseline mission with $0.5 \mathrm{~kg}$ of sample returned per sample return vehicle. The only changes to the mission were to the propulsion systems for in situ use. Table 4 presents the detailed mass breakdown of the baseline, $\mathrm{CO} / \mathrm{O}_{2}$, and $\mathrm{CH}_{4} / \mathrm{O}_{2}$ sample return vehicles. Earth launch savings for the in situ propellants comes not only from the absence of the return propellant at Earth launch, but also the reduction in propellant necessary to send the lighter sample return vehicle to Mars. For this mission, that eliminates the $401 \mathrm{~kg}$ of baseline return propellant and 9 or $6 \mathrm{~kg}$ in descent and TCM propellant 
for the $\mathrm{CO} / \mathrm{O}_{2}$ and $\mathrm{CH}_{4} / \mathrm{O}_{2}$ cases respectively. However, the in situ production plant mass must be added to the Earth launch mass. This adds $234 \mathrm{~kg}$ for $\mathrm{CO} / \mathrm{O}_{2}$ and 231 $\mathrm{kg}$ for $\mathrm{CH}_{4} / \mathrm{O}_{2}$. In the $\mathrm{CO} / \mathrm{O}_{2}$ case, $\mathrm{CO} / \mathrm{O}_{2}$ is cryogenic and the specific impulse is lower than the baseline propellants; therefore, the return propellant, tank, and engine masses are significantly larger than the baseline. However, only the empty tanks and engines are brought from Earth, which adds $54 \mathrm{~kg}$ to the original baseline Earth launch mass. $\mathrm{CH}_{4} / \mathrm{O}_{2}$ has a specific impulse slightly larger than the baseline, but is cryogenic; therefore, the additional tank and engine mass is only 15 kg. Methane also requires hydrogen from Earth for production, which adds $78 \mathrm{~kg}$ of hydrogen and its tank to the $\mathrm{CH}_{4} / \mathrm{O}_{2}$ Earth launch mass.

Total Earth launch masses for $\mathrm{CO} / \mathrm{O}_{2}$ and $\mathrm{CH} /$ $\mathrm{O}_{2}$ are shown in Figure 3 along with the baseline launch mass. $\mathrm{CO} / \mathrm{O}_{2}$ provides the lowest Earth launch mass with a decrease of 13.6 percent from the baseline launch mass. $\mathrm{CH}_{4} / \mathrm{O}_{2}$ had a 9.2 percent decrease from the baseline. Figure 4 shows that all of the launch masses fit within the Earth launch mass margins for the Atlas IIAS for the $\mathrm{C}_{3}$ of each mission opportunity between 2001 and 2009. However, $\mathrm{CO} / \mathrm{O}_{2}$ has the highest mass margin. This makes $\mathrm{CO} / \mathrm{O}_{2}$ more flexible to design changes during development. $\mathrm{CH}_{4} / \mathrm{O}_{2}$ has high mass margins as well, but is lower than $\mathrm{CO} / \mathrm{O}_{2}$; therefore, it does not offer the Earth launch savings of $\mathrm{CO} / \mathrm{O}_{2}$.

With the increases in Earth launch mass margins using $\mathrm{CO} / \mathrm{O}_{2}$ and $\mathrm{CH}_{4} / \mathrm{O}_{2}$, a larger sample return was investigated. The sample return mass was increased for each sample return vehicle from the baseline sample return mass of $0.5 \mathrm{~kg}$. Figure 5 shows sample mass increase plotted against the resulting Earth launch mass margin for the baseline mission model using an Atlas IIAS. As expected, the mass margin decreases as the sample mass increases. All of the cases meet the Atlas IIAS mass margin constraints for larger sample mass returns. The $\mathrm{CO} / \mathrm{O}_{2}$ case, again, has the highest mass margin. However, Figure 5 shows $\mathrm{CH}_{4} / \mathrm{O}_{2}$ with a relatively slow decline in mass margin with increase in sample mass and approaches $\mathrm{CO} / \mathrm{O}_{2}$ at the higher sample return masses. This could suggest $\mathrm{CH}_{4} /$ $\mathrm{O}_{2}$ as a more attractive candidate over $\mathrm{CO} / \mathrm{O}_{2}$ for large sample return missions. For the $\mathrm{CO} / \mathrm{O}_{2}$ case, which is cryogenic and has a significantly lower specific impulse requiring more return propellant than the baseline mission, increasing tank radius becomes a limiting factor for large return sample masses. $\mathrm{CH}_{4} / \mathrm{O}_{2}$ does not encounter the same difficulties because of its slightly higher specific impulse than the baseline, although it is also cryogenic.
Since raising the sample return mass stayed within the Atlas IIAS mass margins, the Atlas IIA was considered as an alternate launch vehicle. Using the Atlas IIA could reduce the launch costs by $34-40 \mathrm{M}$ (FY90 \$). ${ }^{12}$ The Atlas IIA mass margins for the baseline, $\mathrm{CO} / \mathrm{O}_{2}$, and $\mathrm{CH}_{4} / \mathrm{O}_{2}$ cases were plotted with the same increases in sample mass as above. As seen in Figure 6, only $\mathrm{CO} / \mathrm{O}_{2}$ meets the launch mass margins for the Atlas IIA, although, the mass margins are very low in comparison to the Atlas IIAS mass margins. Therefore, mission flexibility is limited with the Atlas IIA use.

The final parameter investigated to use the launch mass margin available was mini-rover redundancy. An additional mini-rover in each sample return vehicle would allow for single rover failure without compromising the return sample or its purity. Also, with two working rovers, the return samples could be obtained faster and with greater selection. To show the effect of the added rover on Earth launch mass margin, increasing sample return mass was plotted against mass margin for one and two rovers for the $\mathrm{CO} /$ $\mathrm{O}_{2}$ case using an Atlas IIAS as the launch vehicle, see Figure 7. As expected, the launch mass margin decreases with the additional rover, but only by three percent. The baseline and $\mathrm{CH}_{4} / \mathrm{O}_{2}$ cases exhibited the same trend. Using an Atlas IIA, the $\mathrm{CO} / \mathrm{O}_{2}$ case was replotted, see Figure 8. This shows that the $\mathrm{CO} / \mathrm{O}_{2}$ case can not only increase in sample mass and carry additional rovers, but it can also use the smaller launch vehicle for sample return masses below $7 \mathrm{~kg}$ per Earth launch.

\section{Concluding Remarks}

Following the baseline mission, $\mathrm{CO} / \mathrm{O}_{2}$ had the lowest Earth launch mass. It was 13.6 percent less than the baseline mission. $\mathrm{CH}_{4} / \mathrm{O}_{2}$ decreased the baseline launch mass by 9.2 percent. Using an Atlas IIAS, CO/ $\mathrm{O}_{2}$ and $\mathrm{CH}_{4} / \mathrm{O}_{2}$ increased the Earth launch mass margins over the baseline mission, with $\mathrm{CO} / \mathrm{O}_{2}$ having the highest mass margin.

Increasing sample return mass was possible for all of the missions using the Atlas IIAS. $\mathrm{CO} / \mathrm{O}_{2}$ retained the highest Earth launch mass margins. Although, $\mathrm{CH} /$ $\mathrm{O}_{2}$ had a slower decrease in launch mass margin than $\mathrm{CO} / \mathrm{O}_{2}$ and showed potential for use in large sample return missions.

Using the Atlas IIA as an alternate launch vehicle to the Atlas IIAS, only $\mathrm{CO} / \mathrm{O}_{2}$ met the Earth launch mass margin. Since the mass margins were lower than with the Atlas IIAS, the flexibility would be limited. However, using the Atlas IIA, which has a price 
tag of $34-40 \mathrm{M}$ (FY90 \$) less than the Atlas IIAS, would save in launch costs.

Adding an additional mini-rover to each sample return vehicle decreased the Earth launch mass margins greatly. However, the baseline, $\mathrm{CO} / \mathrm{O}_{2}$ and $\mathrm{CH}_{4} / \mathrm{O}_{2}$ were all capable of cartying the added rover using the Atlas IIAS. When considering the Atlas IIA as the launch vehicle, only the $\mathrm{CO} / \mathrm{O}_{2}$ case was able to add the extra rover.

Using in situ propellants $-\mathrm{CO} / \mathrm{O}_{2}$ and $\mathrm{CH}_{4} / \mathrm{O}_{2}$ - for the return segment of a Mars sample return mission increases the mission flexibility. For example, larger sample masses can be returned and an additional minirover can also be added for increased redundancy in completing the mission. $\mathrm{CO} / \mathrm{O}_{2}$ is the most advantageous in situ propellant, it can allow for an increase in sample mass, an additional rover, and also a smaller, cheaper launch vehicle.

\section{References}

1. Jet Propulsion Laboratory, "Concepts for a Small Mars Sample Return Mission Using Microtechnology," JPL D-8822, October 1991.

2. Zubrin, R.M., Baker, D.A., and Gwynne, O., "Mars Direct: A Coherent Architecture for the Space Exploration Initiative," AIAA 91-2333, June 1991.

3. Bourke, R., and Kwok, J., "Mars Rover Sample Return Mission," AIAA 89-0417, January 1989.

4. Palaszewski, B., and Frisbee, R., "Advanced Propulsion for the Mars Rover Sample Return Mission," AIAA 88-2900, July 1988.

5. Mars Study Team, NASA Headquarters, "Mars Rover/Sample Return Mission," January 1987.

6. Stancati, M.L., et al., "In Situ Propellant Production for Improved Sample Return Mission Performance," AAS 79-177, 1979.

7. Meyer, T.R. and McKay, C.P., J. Brit. Interplan. Soc., Vol. 42, 1989, pp.147.

8. Ramohalli, K., et al., "Some Aspects of Space Propulsion with Extraterrestrial Resources," J.Spacecraft, Vol. 24, No. 3, May-June 1987, pp.236244.

9. Colvin, J., Schallhorn, P., and Ramohalli, K., "Full System Engineering Design and Operation of an Oxygen Plant," AIAA 91-2444, June 1991.

10. McBride, B.S., and Gordon, S., "Computer Program for Calculation of Complex Chemical Equilibrium Compositions, Rocket Performance, and Chapman-Jouguet Detonations," NASA SP273, Interim Revision, 1976.

11. Frisbee, Robert, "Mass and Power Estimates for Martian In-Situ Propellant Production Systems," JPL D-3648, October 1986.

12. Jet Propulsion Laboratory, "Expendable Launch Vehicles Summary for JPL Mission Planning," JPL D-6936, Rev. B, March 1992. 
Table 1. - Launch Opportunities: Earth-Mars Leg.

\begin{tabular}{|c|c|c|c|}
\hline Type* & $\begin{array}{c}\text { Earliest } \\
\text { Launch }\end{array}$ & $\begin{array}{c}\text { Earliest } \\
\text { Arrival }\end{array}$ & $\begin{array}{c}\mathbf{C}_{\mathbf{3}} \\
\left(\mathbf{k m}^{2} / \mathbf{s}^{2}\right)\end{array}$ \\
\hline 2 & Apr. 12, 01 & Jan. 25, 02 & 8.3 \\
1 & Jun. 7, 03 & Dec. 25, 03 & 10.0 \\
-4 & Nov. 14, 04 & Feb. 5, 07 & 9.6 \\
-4 & Nov. 21, 06 & Jan. 18, 09 & 10.3 \\
2 & Oct. 14, 09 & Sep. 6, 10 & 11.6 \\
\hline
\end{tabular}

1 - Transfer angles less than $180^{\circ}$

2 - Transfer angles greater than $180^{\circ}$

4 - Transfer angles greater than $360^{\circ}$, equivalent to type 2, muti-revolution

at low inclination

Table 2. - Launch Opportunities: Mars-Earth Leg.

\begin{tabular}{|c|c|c|c|}
\hline Type & $\begin{array}{c}\text { Earliest } \\
\text { Launch }\end{array}$ & $\begin{array}{c}\text { Earliest } \\
\text { Arrival }\end{array}$ & $\begin{array}{c}\text { Stay } \\
\text { Time } \\
\text { (days) }\end{array}$ \\
\hline 1 & Apr. 18, 03 & Nov. 10, 03 & 428 \\
-4 & Jan. 24, 06 & Aug. 2, 08 & 748 \\
-4 & Feb. 11, 08 & Sep. 1, 10 & 315 \\
2 & Jul. 7, 09 & May 21, 10 & 128 \\
2 & Aug, 12, 11 & Jul. 9, 12 & 271 \\
\hline
\end{tabular}

Table 3. - Baseline Mission Elements Assumed in In Situ Missions.

\begin{tabular}{|ccc|}
\hline All Stages & Chamber Pressure & $6.89 \mathrm{MPa}$ \\
& Propellant Tank Pressure & $10.0 \mathrm{MPa}$ \\
& Pressurant Tank Pressure & $68.9 \mathrm{MPa}$ \\
\hline MARV Stage II & $\Delta \mathrm{V}$ & $2234 \mathrm{~m} / \mathrm{s}$ \\
& Dry Mass & $33.6 \mathrm{~kg}$ \\
& SRC & $18.3 \mathrm{~kg}$ \\
& Engine area Ratio & 300 \\
& RCS Engines Mass & $0.7 \mathrm{~kg}$ \\
\hline MARV Stage I & $\Delta \mathrm{V}$ & $4100 \mathrm{~m} / \mathrm{s}$ \\
& Dry Mass & $21.5 \mathrm{~kg}$ \\
& Engine Area Ratio & 300 \\
& RCS Engines Mass & $1.5 \mathrm{~kg}$ \\
\hline Lander and Mars Descent & $\Delta \mathrm{V}$ & $200 \mathrm{~m} / \mathrm{s}$ \\
& Dry Mass & $71.5 \mathrm{~kg}$ \\
& Science Module (SAMPEX) & $12.6 \mathrm{~kg}$ \\
& Engine Area Ratio & 400 \\
& RCS Engines Mass & $0.3 \mathrm{~kg}$ \\
\hline BCA and Earth-Mars TCM's & $\Delta \mathrm{V}$ & $33 \mathrm{~m} / \mathrm{s}$ \\
& Dry Mass & $245.2 \mathrm{~kg}$ \\
& Engine Area Ratio & 400 \\
& RCS Engines Mass & $0.44 \mathrm{~kg}$ \\
\hline
\end{tabular}


Table 4. - Itemized Masses For the Sample Return Vehicles and Earth Launch Masses (in kg).

\begin{tabular}{|c|c|c|c|c|}
\hline & & Baseline & $\mathrm{CO} / \mathrm{O}_{2}$ & $\mathrm{CH}_{4} / \mathrm{O}_{2}$ \\
\hline MARV Stage II & Dry Mass & 33.6 & $33.6 \mathrm{~kg}$ & \\
\hline & SRC & 18.3 & $18.3 \mathrm{~kg}$ & $18.3 \mathrm{~kg}$ \\
\hline & Main Engine & 0.69 & 0.85 & 0.71 \\
\hline & RCS Engines (10) & 0.7 & 0.7 & 0.7 \\
\hline & Tanks & 5.4 & 9.2 & 7.2 \\
\hline & Main Burn Propellants & 52.3 & $(75.0)^{\star}$ & $(50.7)^{*}$ \\
\hline 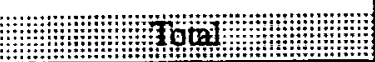 & 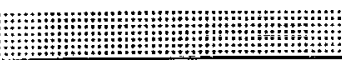 & 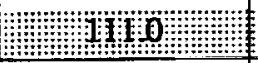 & & 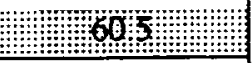 \\
\hline MARV Stage I & Dry Mass & 21.5 & 21.5 & 21.5 \\
\hline & Main Engines (2) & 2.9 & 4.0 & 2.9 \\
\hline & RCS Engines (6) & 1.5 & 1.5 & 1.5 \\
\hline & Tanks & 23.6 & 72.1 & 36.9 \\
\hline & Main Burn Propellants & 349.1 & $(759.5)^{*}$ & $(351.3)^{*}$ \\
\hline 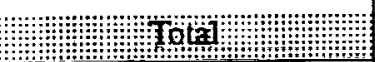 & 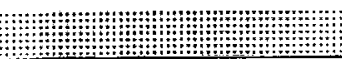 & 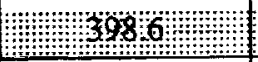 & $99: 0 \%$ & \\
\hline Lander/Mars Descent & Dry Mass & 71.5 & 71.5 & 71.5 \\
\hline & Mini-Rover & 17.0 & 17.0 & 17.0 \\
\hline & SAMPEX & 12.6 & 12.6 & 12.6 \\
\hline & Main Engines (3) & 2.2 & 1.9 & 2.0 \\
\hline & RCS Engines (4) & 0.3 & 0.3 & 0.3 \\
\hline & Tanks & 5.2 & 4.0 & 4.34 \\
\hline & Main Burn Propellants & 37.2 & 30.2 & 32.4 \\
\hline & Hydrogen & N/A & N/A & 34.9 \\
\hline & Hydrogen Tank & N/A & N/A & 42.7 \\
\hline 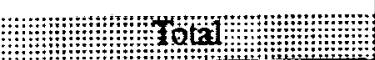 & 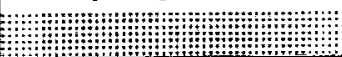 & (8) 1460 - & 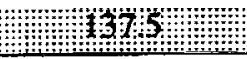 & mas \\
\hline BCAVEarth-Mars TCM's & Dry Mass & 245.2 & 245.2 & 245.2 \\
\hline & Tanks & 3.5 & 3.0 & 3.2 \\
\hline & RCS Engines (12) & 0.44 & 0.44 & 0.44 \\
\hline & RCS Propellants & 12.5 & 10.8 & 11.4 \\
\hline 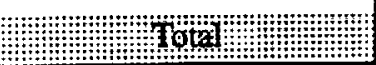 & Dore & HoO6 & 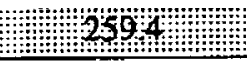 & ooroga \\
\hline $\begin{array}{c}\text { Propellant Production } \\
\text { Plant }\end{array}$ & & N/A & 233.5 & 231.0 \\
\hline SAMPÁTERT & 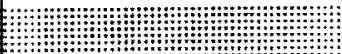 & 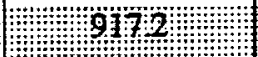 & (1920 & 8323 \\
\hline 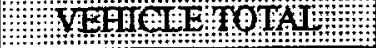 & 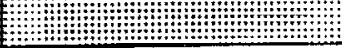 & 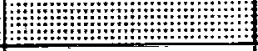 & 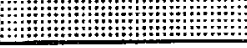 & 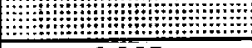 \\
\hline Two Vehicles & & 1834 & 1584 & 1665 \\
\hline Launch Adaptors (3\%) & & 55 & 48 & 50 \\
\hline 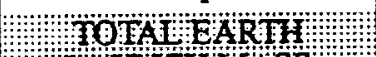 & 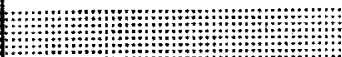 & 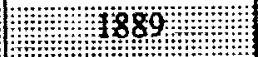 & H:R:163zo:- & To: \\
\hline HA HATHUASSOES & 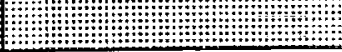 & 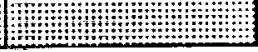 & 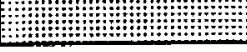 & 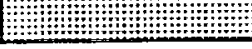 \\
\hline
\end{tabular}




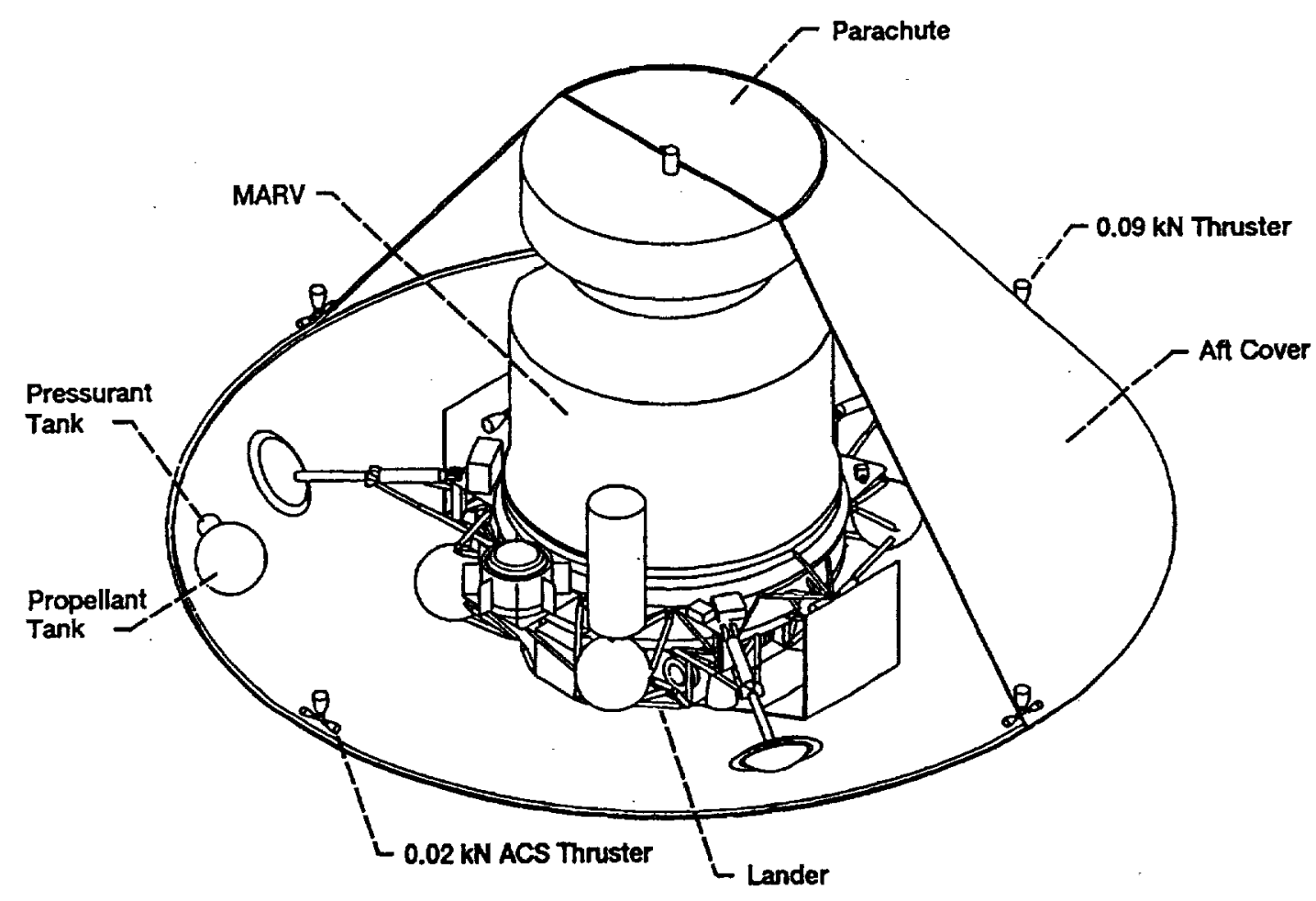

Figure 1. - Baseline Total Sample Return System at Earth Launch.

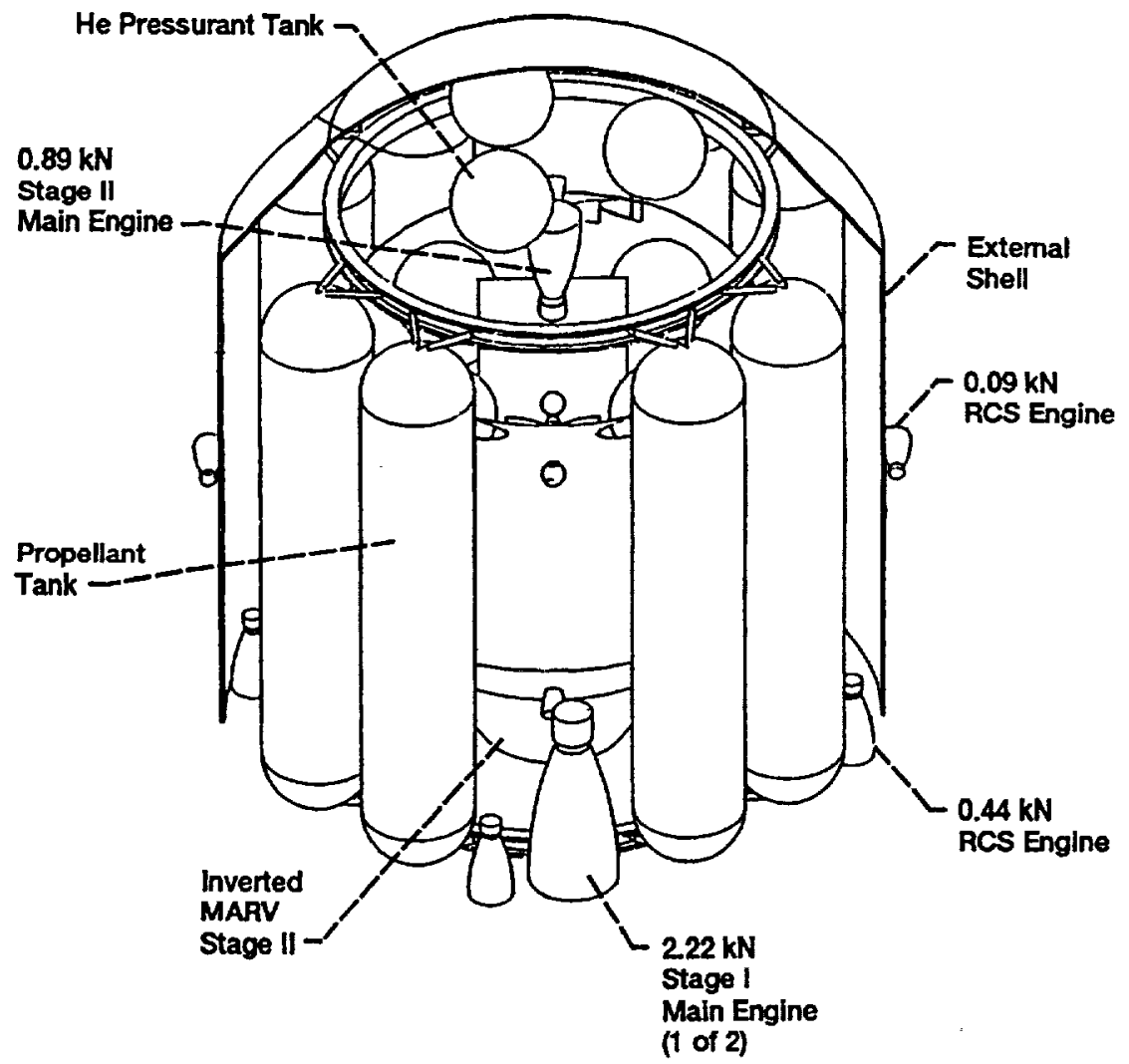

Figure 2. - Baseline MARV - Stages I and II. 


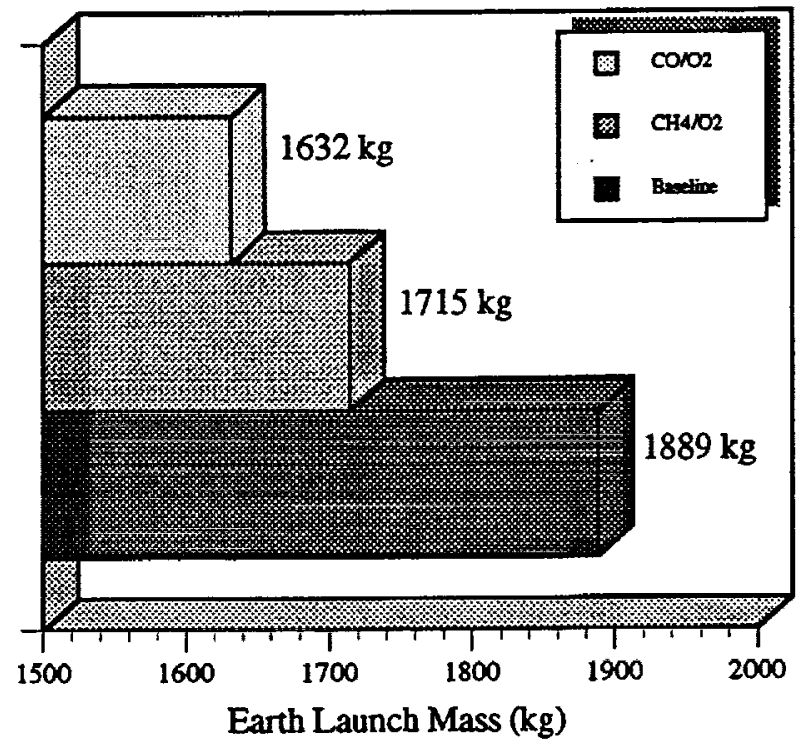

Figure 3. - Earth Launch Masses.

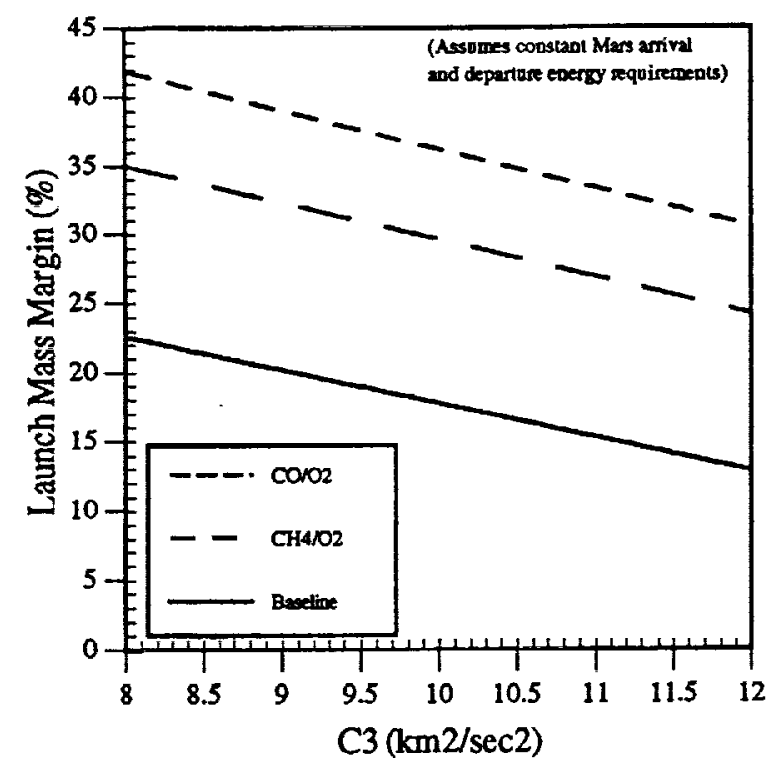

Figure 4. - Earth Launch Mass Margins for Various Mission $\mathrm{C}_{3}$ 's (Atlas IAS).

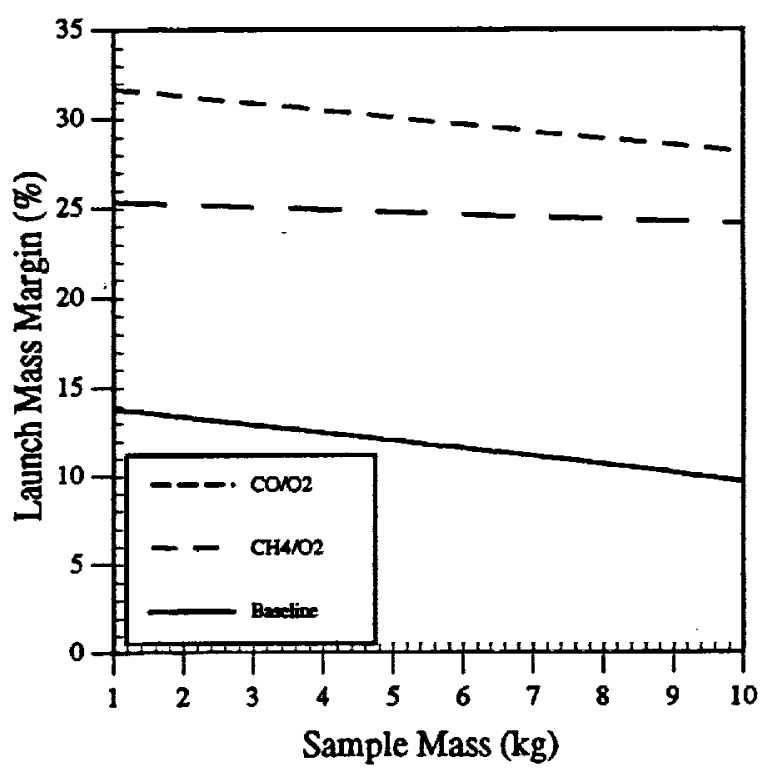

Figure 5. - Sample Return Mass Effects on Earth Launch Mass Margin (Atlas IIAS).

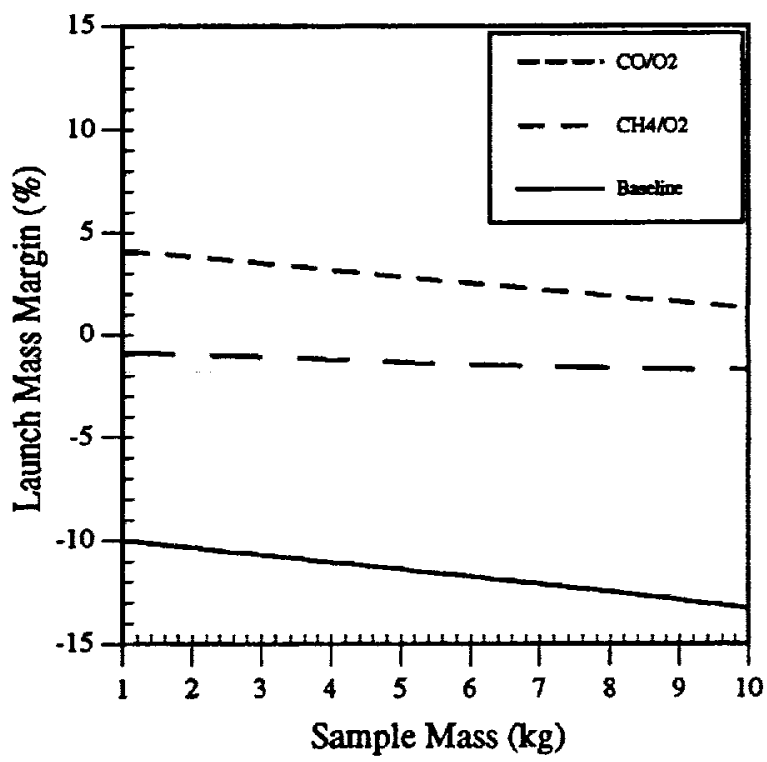

Figure 6. - Atlas IIA Earth Launch Mass Margins. 


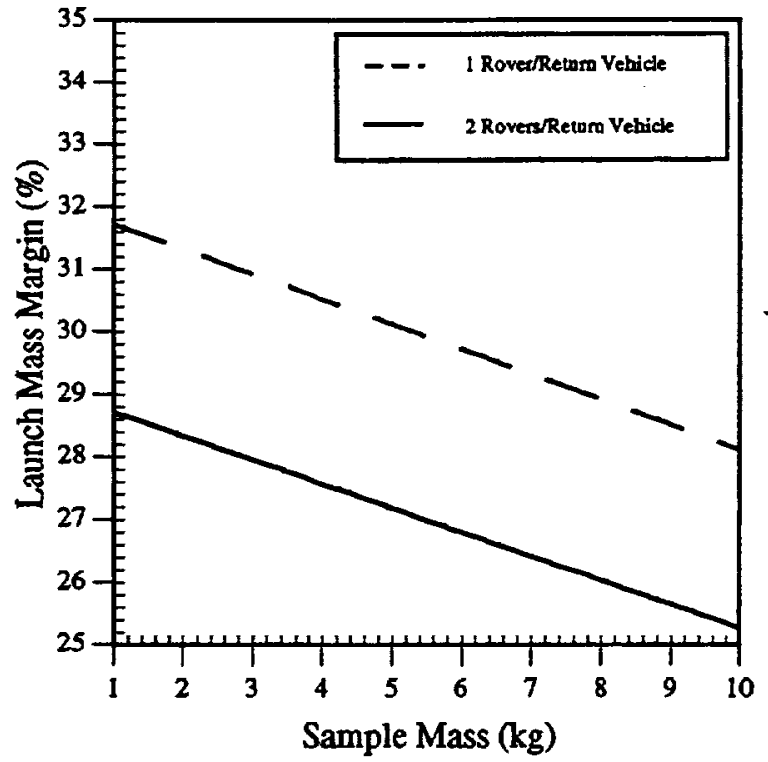

Figure 7. - Additional Rover Effects on Atlas IIAS Launch Mass Margins ( $\mathrm{CO} / \mathrm{O}_{2}$ as MARV Propellants).

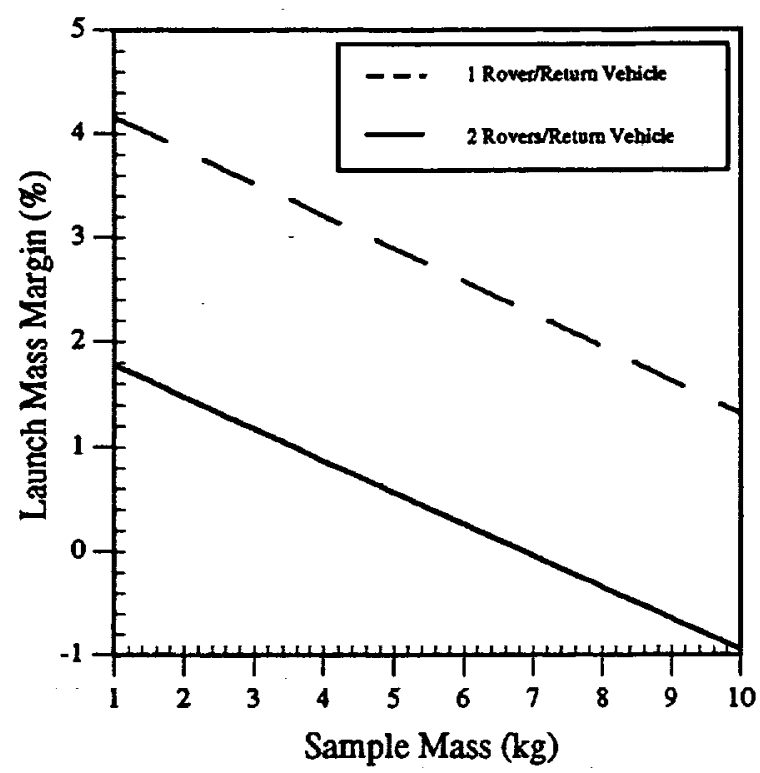

Figure 8. - Additional Rover Effects on Atlas IIA Launch Mass Margins $\left(\mathrm{CO} / \mathrm{O}_{2}\right.$ as MARV Propellants). 
Public reporting burden for this collection of information is estimated to average 1 hour per response, including the time for reviewing instructions, searching existing data sources. gathering and maintaining the data needed, and completing and reviewing the collection of information. Send comments regarding this burden estimate or any ouner aspect of this collection of information, Including suggestions for reducing this burden, to Washington Headquarters Services, Directorate for intormation Operations and Reports, 1215 Jefled

\begin{tabular}{|l|c|c|}
\hline 1. AGENCY USE ONLY (Lave blank) & $\begin{array}{c}\text { 2. REPORT DATE } \\
\text { June } 1993\end{array}$ & $\begin{array}{r}\text { 3. REPORT TYPE AND DATES COVERED } \\
\text { Technical Memorandum }\end{array}$
\end{tabular}

4. TIRE AND SUBTIRE 5. FUNDING NUMBERS

Benefits of In Situ Propellant Utilization for a Mars Sample Return Mission

6. AUTHOR(S)

WU-506-42-72

Mary F. Wadel

7. PERFORMING ORGANIZATON NAME(S) AND ADDRESS(ES)

8. PERFORMING ORGANZATION REPORT NUMBER

National Aeronautics and Space Administration

Lewis Research Center

E-7926

Cleveland, Ohio 44135-3191

9. SPONSORINGMONTORING AGENCY NAME(S) AND ADDRESS(ES)

10. SPONSORINGMONTORING AGENCY REPORT NUMBER

National Aeronautics and Space Administration

Washington, D.C. 20546-0001

NASA TM-106243

AIAA-93-2244

11. SUPPLEMENTARY NOTES

Prepared for the 29th Joint Propulsion Conference and Exhibit cosponsored by the AIAA, SAE, ASME, and ASEE, Monterey, Califomia, June 28-30, 1993. Responsible person, Mary F. Wadel, (216) 977-7510.

12a. DISTRIBUTION/AVAILABILTY STATEMENT

12b. DISTRIBUTION CODE

Unclassified - Unlimited

Subject Categories 20 and 28

13. ABSTRACT (Maximum 200 words)

Previous Mars rover sample return mission studies have shown a requirement for Titan IV or STS Space Shuttle launch vehicles to complete a sample return from a single Mars site. These studies have either used terrestrial propellants or considered in situ production of methane and oxygen for the return portion of the mission. Using in situ propellants for the return vehicles reduces the Earth launch mass and allows for a smaller Earth launch vehicle, since the return propellant is not carried from Earth. Carbon monoxide and oxygen $\left(\mathrm{CO} / \mathrm{O}_{2}\right)$ and methane and oxygen $\left(\mathrm{CH}_{4} / \mathrm{O}_{2}\right)$ were investigated as in situ propellants for a Mars sample return mission and the results were compared to a baseline study performed by the Jet Propulsion Laboratory using terrestrial propellants. Capability for increased sample return mass, use of an alternate launch vehicle, and an additional mini-rover as payload were included in the present study. $\mathrm{CO} / \mathrm{O}_{2}$ and $\mathrm{CH}_{4} / \mathrm{O}_{2}$ were found to decrease the baseline Earth launch mass by 13.6 and 9.2 percent respectively. This resulted in higher payload mass margins for the baseline Atlas IIAS launch vehicle. $\mathrm{CO} / \mathrm{O}_{2}$ had the highest mass margin. And because of this, it was not only possible to increase the sample return mass and carry an additional mini-rover, but was also possible to use the smaller Atlas IIA launch vehicle.

14. SUBJECT TERMS

Propulsion; Mars; Rocket engines; Extraterrestrial resources

17. SECURTY CLASSIFICATION OF REPORT

Unclassified

\author{
18. SECURITY CLASSIFICATION \\ OF THIS PAGE \\ Unclassified
}

19. SECURTY CLASSIFICATION OF ABSTRACT Unclassified 